\title{
CRIMINAL LAW ASPECTS OF COMBATING FAKE NEWS IN POLAND
}

\section{Marcin WIELEC ${ }^{1}$}

This scientific paper analyzes legal criminal protection against fake news in Poland. First, it presents introductory comments on issues related to the main research area. The general characteristics of substantive criminal law in Poland are also presented. The presentation of the characteristics of formal criminal law is that procedural law or criminal procedures will also have a similar character. The next piece of the analytical puzzle is the characteristic offake news. All these parts will give rise to the analysis offake news and criminal law in Poland. This refers to the correlation between these designations. Following the above discussion, draft legislation on fake news in Poland is presented. The comments in this section will show how national law can regulate fake news and legal liability under this phenomenon. At the end of the paper, a short summary contains conclusions related to the analyzed matter.

\begin{tabular}{l|l} 
fake news \\
| & criminal law \\
Poland \\
freedom of expression \\
fegal protection
\end{tabular}

\section{Introduction}

This paper aims to present the current legal status regarding the conditions for incurring criminal liability for acts considered to be 'fake news' (i.e., disinformation activities) in the Polish legal system.

The Polish criminal law system consists of two separate, though highly harmonized areas. The first area of criminal law is substantive law, the legal basis of which is the Penal Code Act of June 6,1997. The other area of criminal law is formal criminal law, also known as procedural criminal law, or simply the criminal procedure, the legal basis of which is the Code of Criminal Procedure Act of June 6,1997.

1 | Head of the Institute of Justice, Warsaw, Poland; Head of the Department of Criminal Procedure, Faculty of Law and Administration, Cardinal Stefan Wyszynski University, Warsaw, Poland; marcin.wielec@iws.gov.pl. 
Substantive criminal law, that is, the regulations essentially contained in the Penal Code, provides for the basic principles and conditions of the broadly understood criminal liability of persons, or in other words, their liability for offenses. It is in this area (the Penal Code) that answers can be found as to who is to be held criminally liable, what conduct or acts are crimes, what penalties are provided for offenses committed, etc.

In contrast, formal criminal law (procedural criminal law, criminal procedure) mainly consists of the regulations contained in the Code of Criminal Procedure, which defines the rules of investigation and prosecution activities for detecting the offender, presenting charges or a bill of indictment, and bringing them to a trial. As a side note, this Act governs matters related to the conditions for initiating criminal proceedings, collecting, recording, and taking evidence, the rules of adjudication, or matters related to the bodies and authorities involved in the criminal procedure. Thus, formal law serves as a trigger that initiates the application of substantive criminal law, which means that the former plays an auxiliary role in the latter. ${ }^{2}$

Our analysis focuses on these two areas and their coverage of the issue of fake news. That fake news is something negative - judging by the very name - is clear from the use of the word 'fake', meaning 'false', 'counterfeit', 'fabricated', or 'imitated'.

Since fake news is something negative, it is worth considering what protection against it there is in the Polish legal system - in a system that is utterly dominated by the authority of state institutions, affecting criminal law and procedure as well.

\section{General characteristics of substantive criminal law in Poland}

As mentioned above, the Polish criminal law system in its basic version starts with the Penal Code (PeCo) as the fundamental legal act in this area. It is a rather extensive, complex, and detailed legal act that consists of three parts. The first is general governing the rules of criminal liability and related issues. The general part contains, among others, a description of what an offense is. According to PeCo Art.1, only a person who commits an act punishable under the law in force at that time incurs criminal liability.

Nevertheless, a prohibited act is not a crime if the harm caused to society is negligible, nor does the offender of a prohibited act commit a crime if they cannot be attributed to any culpability at the time of the Act. Further, PeCo Art. 2 states that only a person with a specific legal duty to prevent criminal consequences may be held criminally liable for a consequential offense committed by omission. Art. 5 of the Penal Code stipulates that the Polish Penal Code (criminal law) applies to an offender who commits a prohibited act in the territory of the Republic of Poland or on a Polish vessel or aircraft unless the Republic of Poland is a party to an international agreement stating otherwise. Elsewhere, a catalog of penalties for offenses is also provided. Hence, under PeCo Art. 7 (in the system of Polish criminal law), a crime is either a felony or a misdemeanor. Furthermore, a felony is a prohibited act punishable by imprisonment for a term not less than three years, or a more severe penalty. 
In contrast, a misdemeanor is a prohibited act punishable by a fine of more than 30 daily rates or more than PLN 5,000, a penalty of restriction of liberty for more than one month, or imprisonment for more than one month. There is also a reservation that a felony must involve criminal intent (deliberation), while a misdemeanor may be committed unintentionally, as provided by the law. A prohibited act is committed intentionally if the offender has the intent to commit it, that is, either they are willing to commit it or are foreseeing the possibility of committing it and accepting it. A prohibited act is committed unintentionally if the offender, having no intent to commit it, still fails to exercise due care under the circumstances, even though they foresaw or could have foreseen a possibility of committing the prohibited act. As to the age threshold above which one may be held criminally liable, the Penal Code provides that its rules apply to anyone aged 17 years or older who commits a prohibited act. A minor aged 15 or older who commits a prohibited act in specific instances provided in the Penal Code may be held liable under the principles set out in the Code if deemed appropriate given the circumstances of the case and the level of mental development of the offender, the characteristics and personal situation, and especially if the previous attempts at educational or correctional measures have proved to be ineffective. The Penal Code include Art. 134 (assassination attempt on the life of the President of the Republic of Poland), Art. 148 § 1, 2 or 3 (homicide), Art. $156 \S$ 1 or 3 (grievous bodily harm), Art. $136 \S 1$ or 3 (active assault or insult of a representative of a foreign state), Art. 166 (piracy, i.e., hijacking aircraft or a sea vessel), Art. $173 \S 1$ or 3 (causing a traffic disaster), Art. $197 \S 3$ or 4 (rape and sexual extortion), Art. $223 \S 2$ (active assault), Art. $252 \S 1$ or 2 (taking or holding a hostage), and Art. 280 (robbery). If an offender commits a misdemeanor after turning 17, but before turning 18 years old, the court will adopt educational, therapeutic, or correctional measures prescribed for juvenile delinquents, instead of a penalty, if it is deemed appropriate given the circumstances of the case and the level of mental development of the offender, the characteristics, and the personal situation. In addition to penalties, the Polish criminal law system also employs penal measures. Under the Penal Code, penal measures include deprivation of public rights; disqualification from specific posts; the exercise of specific professions or engagement in specific economic activities; disqualification from activities involving raising, treating, and educating minors or taking care of them; prohibition of staying in certain communities and locations; contacting certain individuals or leaving a specific place of residence without the court's consent; prohibition of entering a mass event; prohibition of entering gaming centers or participating in games of chance; an order to leave premises jointly occupied with the aggrieved party, disqualification from driving, monetary performance, and public announcement of the sentence.

The second part is specific and lists individual and individualized acts recognized as offences in the criminal system, such as offences against peace, mankind and war crimes, offences against the Republic of Poland, offences against defense capabilities, offences against life and health, offences against public safety, offences against traffic safety, offences against the environment, offences against freedom, offences against freedom of conscience and religion, offences against sexual freedom and morals, offences against the family and guardianship, offences against good names and personal integrity, offences against the rights of people performing paid work, offences against state and local government institutions, offences against the administration of justice, offences against elections and referendums, offences against public order, offences against the protection of information, offences against the reliability of documents, offences against 
property, offences against economic transactions and property interests in civil law transactions, offences against trading in currencies

The last, third, part of the Penal Code is devoted to the criminal liability of military service members. It is named the 'military part' and governs the principles of criminal liability solely in relation to soldiers, setting out individual blocks of offenses that can only be committed by soldiers.

\section{Characteristics of formal criminal law (procedural law, criminal procedure)}

The basic legal act in the other area of criminal law, that is, the area of formal criminal law, procedural law, or simply the criminal procedure, is the Code of Criminal Procedure. It sets out the principles of the implementation of substantive criminal law, while its main objective is to determine whether a prohibited act - an offense - has been committed or not, and the rules for detecting the offender and bringing them to criminal liability. The Code of Criminal Procedure also lays down the rights and obligations of the bodies involved in the procedure, including courts and prosecutors. It indicates participants of criminal proceedings such as the suspect, defendant, aggrieved party, defense attorney, and their rights and obligations. In general, we can conclude that the criminal process aims to achieve substantive criminal justice and a state of procedural criminal justice. Hence, the Code of Criminal Procedure in Art. 2 provides that the purpose of the Code is to establish rules for the criminal process so that: 1) the offender is detected and held criminally responsible, and no innocent person is so held liable; 2) through the correct application of the measures provided for in criminal law and the disclosure of the circumstances conducive to committing an offense, the objectives of criminal proceedings are achieved not only with regard to combating crime but also in preventing it and strengthening the respect for the law and the principles of social coexistence; 3 ) the legally protected interests of the aggrieved party are secured, while their dignity is fully respected; and 4) the case is resolved within a reasonable time.

The criminal process is ius publicum, a segment of law in which a public authority always prevails. As a result, a public body is stronger in terms of competence, organization, and power than an individual, which enables it to arbitrarily (authoritatively) influence an individual by influencing (shaping) the legal position of a person or other organizational units by issuing a decision, which is defined as a form of public administrative activity. ${ }^{3}$ Hence, it is emphasized that as a differentia specifica, this public law segment establishes direct coercion exercised by state authorities in the event of disobedience to the applicable norms, which is not the case in the segment of civil law.

The guiding principle of criminal proceedings is the principle of truth expressed in Art. $2 \S 2$ of the Code of Criminal Procedure, according to which any determinations must be based on true factual findings. The Code of Criminal Procedure is a much larger act than the Penal Code. In general, the criminal process is characterized by the authority 
of public bodies, coercion exercised by the state, and a considerable conflict of values. ${ }^{4}$ There is no doubt that criminal law and criminal procedure are a domain of state bodies, where there is no place for private feelings or actions. In its adjudication, the court passes the final verdict on behalf of the state, and the public prosecutor, when presenting and pressing charges, performs their duties under the mandate of the state. This implies an obvious conclusion about a stronger position and a clear procedural privilege of these bodies at the expense of others representing the specific interests of the remaining participants. For systemic reasons, state structures always prevail over private participants in criminal proceedings. It manifests itself in the procedural position of the court and the prosecutor as two bodies with strong competencies in the criminal process. When one considers the guarantees under the Constitution of the Republic of Poland, such as the right to privacy, the right to information, and the right to the fair criminal process, it is clear that in criminal proceedings, there is a collision of objectively understood interests with not infrequently subjectively delimited interests of individual entities involved in the criminal process. As a result, situations emerge where a specific value (or values), in combination with the principles of criminal proceedings, force a choice that essentially will never be entirely right or equitable, as something will be chosen over something else, and that something else will be sacrificed. The above collision is visible, among others, under the assumption of seeking truth in criminal proceedings. However, it turns out that in certain specific situations, the truth remains unattainable in criminal proceedings. As we can see, these are pivotal issues in the heart of the criminal process. Meanwhile, a conflict is generated because it turns out that in criminal proceedings, the truth, albeit a value raised to the rank of one of the most important principles, is not reached at any cost. In this context, an important issue in criminal proceedings is to collect, interpret, and introduce evidence as the primary elements that confirm or deny someone or something. Evidence is taken at the request of the parties or ex officio. It is important that the taking of evidence follows the rules provided in the Code of Criminal Procedure.

\section{Characteristics of fake news}

The above-described area of Polish criminal law today lacks provisions on criminal liability for fake news offenses. In other words, there is no such category as a fake news crime, and therefore there is no criminal liability for activities involving fake news. Admittedly, this is not surprising, as there is no doubt that establishing a legal construct of a fake news offense means venturing into a multifaceted and complex effort, the effects of which are often difficult to predict. The scale of the impact of fake news can be either laughable, with no consequences, penalty, or terrifying. The difficulty lies in the construction of a possible fake news offence, and in predicting the effects of fake news that may emerge in various areas covered by law.

Since the legal acts currently in force in Poland do not contain a definition of a fake news offense, it is worth presenting at least briefly one of the many definitions in the scholarly literature. It is emphasized, among others, that the term 'fake news' is a neologism and has no formal definition. Roughly speaking, it is a deliberate message intended 
to mislead the recipient. It is neither true nor lie. Fake news is usually based on disinformation or a prank, often containing some elements of truth. 'Fake news can pretend to be real information, articles, social media posts, memes, etc. It can be created with various intentions, ranging from fraud, propaganda tools, sensationalism, to a prank. ${ }^{5}$ Moving in this direction, in very general terms, we can define fake news as: (1) a false message with the characteristics of a true one; (2) a satirical message created deliberately for entertainment purposes; (3) one which we think is true, but it is false; (4) one designed to mislead for financial, political, and prestige gains; and (5) a false message, regardless of the intention of the sender.' ${ }^{6}$ In dictionary terms, "fake news" is defined as untrue, false information most often disseminated by tabloids with a view to causing controversy or slandering or libeling someone (usually a politician). ${ }^{7}$ Therefore, the concept of fake news is often referred to as various cases of information manipulated or tampered with by authors/ broadcasters.' $^{8}$

It is clear then that criminal liability for fake news is nowhere to be found. This is extremely difficult because the creation, publication, and use of fake news are the various stages of a premeditated activity that entails a specific kind of liability. The kind of liability for this type of act depends only on the legislator. That is why liability for fake news, for its production, dissemination, and effect, may take the form of civil, criminal, administrative, or disciplinary liability.

There is no doubt that the most severe and spectacular form of legal liability is criminal liability. If we compare this area of criminal law to other areas of law, such as civil law or administrative law, it is a criminal law that interferes with the guarantees of the rights of an individual and thus is strictly controversial. Criminal liability carries the abovementioned specific load of power on the part of public administration bodies in relation to the legal position of an individual. Certain behaviors should always be penalized under the criminal law regime as the ultima ratio. Therefore, if the legislator decides to introduce criminal liability for specific conduct, it must do it very prudently, thoughtfully, effectively, and efficiently. A legal provision in criminal law should be structured so that it is understandable and, above all, effective. To this end, we should also add the structure of the provisions of procedural criminal law. This is especially true when taking evidence. If a specific type of a new offense is to be introduced to the criminal law system, then it is also necessary to consider the evidence-related process for the offense. The question is how to prove it, what evidence to produce, how to produce it, how to consolidate the necessary evidence, and finally arrive at the truth. With fake news, there will often be non-standard evidence at variance with what is characteristic of criminal proceedings, such as witness statements, etc. Here, digital evidence will be key, and the problem of digital materials in the criminal process is only poorly recognized at this stage.

Another problem is the interference of criminal law, in general, with liability for fake news. There appears to be a real conflict-driven confrontation. With fake news, there is a unique collision of values. On the one hand, there is a constitutional right to freedom of speech, the right to information, etc., there is a guaranteed right to protection of honor, good name of an individual or other entity, etc., and the construction of a fake news offence

5 | https://cik.uke.gov.pl/news/fake-news-czyli-falszywa-prawda,191.html(Accessed: April 8, 2021). 6 | Palczewski, 2019, p. 17.

7 | https://sjp.pwn.pl/mlodziezowe-slowo-roku/haslo/fake-news;6368870.html (Accessed: May 10, 2021).

8 | Daniel, 2018, p. 99. 
will naturally limit and interfere with the most important rights in a democratic state. Fake news is not only information that may infringe upon the good names of individuals. After all, fake news can also cause enormous damage in the public sector, such as national security and international security.

Therefore, the problem lies in the development of criteria for assessing whether something is fake news, proving it, indicating entities responsible for fake news, etc. Generally, the problem is how to contain the phenomenon of fake news, whether criminal law is needed here, or perhaps the problem should be resolved with soft instruments, such as civil law.

What eventually is at stake is the huge load of various collisions generated by fake news. In Poland, it is often pointed out that various groups operating here often fall prey to censorship, with their published content being removed or blocked on the Internet. There is also a growing number of fake news on websites, and when someone wants to defend themselves against it, they are prevented from asserting their rights. Time will show that there will be an extreme need for regulations to protect freedom of speech on the Internet, and to protect against the abuse of large internet corporations. Even so, such regulations will have to allow, with full control, combatting violations of the law in social networks. What is key are the criteria for assessing fake news, its content, the degree of fraud, the degree of violation of the truth and, last but not least, its effect; these criteria will determine the area of law, whether civil, administrative or criminal, should govern criminal liability for fake news. Hence, the following classification of fake news can be proposed, where the criterion for assessment is the type and effect of disinformation. The first group covers first-degree fake news, which represents the gravest misrepresentation, false information, and content load, with the greatest impact. The examination covers who and what such fake news concerns and whether the creation and publication of fake news do not threaten the highest values enjoying protection under law, such as public order, health, and life of citizens. In this case, such actions should be penalized under criminal law. In other words, the construction of an appropriate criminal provision should be envisaged, which would penalize fake news as a cause of action with enormous effects on multiple levels. Examples would include alteration, manipulation, falsification of indisputable historical facts, or presentation of the course of a certain event carrying a huge social load in a manipulated, falsified manner to misrepresent, ridicule, or discredit key historical facts or state leadership, or creation and dissemination of such information that will endanger public security.

However, the constituent elements of the crime must be precisely defined and should include, among others, the intent and purpose of creating or disseminating fake news. The next group consists of second-degree fake news, which would be an act with a much more limited impact, affecting the reputation of a person or a fact and violating only the private area of the person or fact. There is no major impact on the public, but the entity that is the main subject of fake news is discomforted. In this case, the message is too satirical and too distorted so that, in principle, any reasonable bystander would point to a significant transgression of, for example, aesthetic or moral norms. Although private interests are violated, penal measures need not be used. Therefore, the best domain of legal liability is civil law and civil action, along with the use of tools that exist even now (court action, redress, etc.). In this case, it is under civil law that all issues related to the creation, dissemination, and use of fake news will be resolved. The third group features third-degree fake news, which would be manipulated content and false information within 
one's professional group. This is a much more limited area of impact than that indicated above. An important factor here is the professional or social group, which functions according to the generally established principles of professional deontology. In this case, disciplinary/professional liability comes into play, that is, a type of liability reserved for a specific group of entities. Finally, fourth-degree fake news would be a minor, essentially non-punitive, formal-only (i.e., non-consequential) production and dissemination of fake news for satire, fun without major consequences for production, distribution, or use. This type of fake news is not penalized in any way.

\section{Fake news and criminal law in Poland}

The conclusion from the above analyses is quite straightforward: at the moment, in the criminal legal system in Poland, there is no direct provision that would make the creation, dissemination, use of fake news, and so on. This does not mean, however, that it is impossible to find legal provisions that indirectly trigger criminal liability for false information.

First, it should be noted that the Penal Code is the basic legal act in the Polish criminal law system. Where fake news takes the form of stalking, discrediting, or harming the good name of a person, etc., then the above legal act provides for the offense of persistent harassment. Pursuant to PeCo Art. 190a, any person, who by persistent harassment of another person or their next of kin evokes a justified sense of threat, humiliation, or distress, or significantly violates their privacy, is subject to the penalty of deprivation of liberty for a period of six months to eight years. Any person who pretends to be another and uses their image, personal data, or other data serving their public identification to cause them property or personal damage is liable to the same penalty. If an act specified above results in a suicide attempt by the person, the offender is liable to the penalty of deprivation of liberty for a term from two to twelve years. This prohibited act is prosecuted ex officio but upon the motion of an injured party.

If the fake news is to present, for example, a person, institution, then it is an offense of defamation. In this case, according to PeCo Art. 212, any person who slanders another person, a group of persons, body corporation, or an organizational unit without legal personality for conduct or characteristics that may discredit them in public opinion, or result in a loss of confidence necessary to perform duties in their position, occupation, or type of activity, is liable to fines or the penalty of restriction of liberty. If the offender commits the above act through the mass media, they are liable to fines, restriction of liberty, or deprivation of liberty for up to one year. If the offender commits the act specified in $\S 1$ through the mass media, they are liable to fines, the penalty of restriction of liberty, or deprivation of liberty for up to one year. In the event of a conviction for the offense specified above, the court may award exemplary damages to the aggrieved party or the Polish Red Cross, or another social cause designated by the aggrieved party. Here, too, the offense of defamation analyzed here is prosecuted on a private complaint.

A very similar regulation can be found in Art. 216 of the Penal Code, concerning the offense of insult, under which any person who insults another person in their presence, publicly in their absence, or with the intention that the insult will reach the person, is liable to fines of the penalty of restriction of liberty. Any person who insults another 
person using the mass media is liable to fines, restriction of liberty, or deprivation of liberty for up to one year. Private prosecution also applies to this offense.

Where disinformation leads to fraud, it is possible to apply PeCo Art. 286, whereby anyone who (with the intent to achieve a material benefit) causes another person to unfavorably dispose of their property, or the proper of a third party, by misleading the person, or by taking advantage of a mistake or an inability to properly understand the action undertaken, is liable to the penalty of deprivation of liberty for a term between six months and eight years.

It is also possible to imagine situations in which false information constitutes the basis for action against the security of the state. In such cases, PeCo Art. 132 provides for liability for intelligence disinformation, according to which any person, who, while providing intelligence services to the Republic of Poland, misleads a Polish state authority by delivering counterfeit or altered documents other items, or by concealing the true information or furnishing false information of essential importance to the Republic of Poland, is liable to the penalty of deprivation of liberty for a term between one-year and ten years.

Another example where the creation or dissemination of fake news may be part of the structure of a specific offense is the provision of Art. 257 of the Penal Code, concerning the offense of racism and stipulating expressly that any person who publicly insults a population group or an individual because of their national, ethnic, racial, or religious affiliation, or irreligiosity, or for these reasons violates personal integrity of another person, is liable to the penalty of deprivation of liberty for a term of up to three years. An interesting case is the provision of the Act of December 18, 1998, on the Institute of National Remembrance - Commission for the Prosecution of Crimes against the Polish Nation (Journal of Laws of 2021, item 177). This is Art. 55, according to which anyone who publicly and contrary to the facts denies crimes referred to in the Act is subject to a fine or imprisonment of up to three years. The judgment is made public. It is about the crimes, among others, committed on persons of Polish nationality or Polish citizens of other nationalities in the period from November 8, 1917, to July 31, 1990, that is, Nazi crimes, communist crimes, crimes of Ukrainian nationalists and members of Ukrainian formations collaborating with the German Third Reich, or other offenses constituting crimes against peace, mankind, or war crimes, etc.

\section{Draft legislation on fake news in Poland}

Given the above considerations, the legislative work envisaging liability for fake news in Poland includes a draft act on the protection of the freedoms of social network users, which was conveyed on January 22, 2021, to the chancellery of the Prime Minister requesting an entry in the list of legislative work of the Council of Ministers. ${ }^{9}$ The new legislation is intended to protect the constitutional right to freedom of speech, as well as the rights of individuals violated by anonymous Internet users. 
In the preamble, the Act is adopted in recognition of the special constitutional value of freedom of speech to strengthen its role in the search for truth, the functioning of a democratic state, respect for the principle of freedom of expression, and human dignity.

The purpose of the Act is to create conditions for 1) supporting freedom of expression; 2) guaranteeing the right to truthful information; 3) improving the degree of protection of human rights and freedoms in online social networks made available in the territory of the Republic of Poland, with at least one million registered users; and 4) observance by online social networks of the freedom of expression, sourcing information, disseminating information, expressing religious and philosophical views and beliefs, and the freedom of communication.

As the first-ever instrument in the Polish legal system, the Act introduces concepts necessary for the construction of liability for fake news, creating a specific catalog of statutory expressions. See the following examples:

- an online social network service is understood as a service provided electronically, allowing users to share any content with other users or the general public, which is used by at least one million registered users in the country.

- a service provider supplies online social network services, involving the storage of information provided by users in an online social network at their request, with at least one million registered users.

- a country representative is an individual or a body corporation with a place of residence or registered office in the territory of the Republic of Poland, having the exclusive right to represent a service provider in the territory of the Republic of Poland and to conduct internal audit and control procedures on its behalf.

- a user is a service recipient and an individual, a body corporate or an organizational unit without legal personality that uses an online social network service, even in the absence of a user profile;

- a user profile is a set of settings for the working environment of a social network service user.

- disinformation is false or misleading information, produced, presented, and disseminated for profit or violation of the public interest;

- content of criminal nature praises or incites the commitment of prohibited acts as specified under articles of the Penal $\operatorname{Code}^{10}$ or meeting the criteria of a prohibited act.

illegal content violates personal rights, disinformation, the content of criminal nature, as well as content that violates morality, in particular, by disseminating or praising violence, distress, or humiliation.

The limitation of access to content covers all acts and omissions taken in any form to limit access to content posted on online social network service, including by deleting a user-posted content that is not illegal and a limitation of access to content through the algorithms used by the service provider, or tags that indicate possible violations in the published content.

- a limitation of access to the user's profile is removing or preventing access to the user's profile, limiting or preventing the sharing of content on the user's profile, including through the algorithms used by the service provider, which limits the display of content posted by the user or tags that indicate possible violations in the published content.

10 | The following articles of the Penal Code: 117-119, 127-130, 133, 134-135, 137, 140, 148-150, 189-189a, 190a, 194-204, 222-224a, 249-251, 255-258, 343 of the Penal Code Act of 6 June 1997 (Journal of Laws of 2020, items 1444 and 1517). 
A crucial body to be established under this Act is the Freedom of Speech Council. It is a public administration body monitoring the observance by social network services of freedom of expression, freedom to source information, disseminate information, express religious and philosophical views and beliefs, and freedom of communication.

In the context of legal liability, one should note that the sanctions provided for in this Act are mainly administrative penalties. These are fairly high fines, ranging from PLN 50,000 to PLN 50,000,000. These are administrative fines imposed by the Freedom of Speech Council. For example, a financial penalty is imposed on a service provider who fails to fulfill the obligation to

1) prepare the report referred to in Art. 15 (1);11

2) appoint a country representative referred to in Art. 16 (1);12

3) immediately notify the President of UKE (Office of Electronic Communications) of the appointment or change of its country representative and provide its details, as referred to in Art. 16 (3). ${ }^{13}$

4) immediately inform the President of UKE of any change in the details referred to in Art. 16 (4):;14

(5) publish in an online social network in a visible, directly and permanently accessible manner the full details referred to in Art. 16(5);:15 6) provide the persons conducting an internal audit and check process with training, as referred to in Art. 17 (1);:16

7) put in place an effective and understandable internal audit and check process in the Polish language, on matters referred to in Art. 19 (1).17

11 | Art. 15 (1): A service provider who receives over 100 user complaints in a calendar year regarding dissemination of access to unlawful content, a limitation of access to content or a limitation of access to the user's profile, is obliged to prepare a semi-annual report in the Polish language concerning the resolution of such complaints and to publish it on its social network site no later than one month after the end of a six-month period.

12 | Art. 16 (1): A service provider is required to appoint at least one, but not more than three, representatives in the country.

13 | Art. 16 (3): A service provider is obliged to immediately inform the President of UKE about the appointment of a representative in the country or a change to the person, and to provide their data, including e-mail address and address for service. Where the country representative is a body corporate, a service provider provides the data of natural persons authorized to act on behalf of that body corporate.

14 | A service provider is obliged to immediately inform the President of UKE about any change of details.

15 | Art. 16 (5): A service provider is obliged to publish in an online social network in a clearly visible, directly and permanently accessible manner: 1 ) full details of its country representative, including the e-mail address and address for service, and if the country representative is a body corporate, also the details of natural persons authorized to act on behalf of that body corporate; 2 ) full details of the service provider, including the full name of the entrepreneur running the social network site or their name and surname, registration address or residence address, address for service, registration details and e-mail address.

16 | Art. 17 (1): A service provider provides persons conducting internal audit and check processes with regular, at least every six months, training in the Polish language.

17 | Art. 19 (1): A service provider is obliged to put in place, in the Polish language, effective and understandable internal audit and check processes in matters relating to user complaints concerning:1) a limitation of access to content; 2) a limitation of access to the user's profile; 3) dissemination of access to unlawful content. 
8) post on the online social network site, in the Polish language and available to all users, the terms of use of the online social network site, including the internal audit and check process referred to in Art. 19 (2). ${ }^{18}$

9) provide a visible, directly, and permanently available mechanism for submitting complaints under the internal audit and check process referred to in Art. 19(3). ${ }^{19}$

10) implement a Council decision to restore the previously limited access to content or the previously limited access to the user's profile, as referred to in Art. 25(1);20 etc.

Further, a service provider is liable to a financial penalty for the failure of its country representative to fulfill the obligation to consider a user complaint filed under the internal audit and check processes and to provide responses and any information to institutions and authorities in relation to any conducted proceedings.

When imposing a financial penalty, the Council considers the following: 1) the impact of the service provider's omission on the extent of disinformation caused; 2 ) the degree of breach of the public interest; 3 ) the frequency of past breaches of an obligation or breach of a prohibition of the same type as the breach of an obligation or breach of the prohibition, as a result of which the penalty is to be imposed; 4) record of penalties for the same conduct; and 5) actions taken by the party voluntarily to avoid the consequences of a violation of the law.

The only element related to criminal law is the activation of prosecution authority. A public prosecutor's authorization to act at every procedural level follows mainly from the provisions of the source act for the prosecutor's office, which is the Public Prosecutor's Office Act of June 20, 1985 (Journal of Laws of 2011, No. 270, item 1599, as amended). In the Polish legal system, the public prosecutor's office acts as a body that ensures the rule of law in all legal proceedings. The task of the prosecutor's office is to uphold the rule of law and to supervise the prosecution of offenses. A public prosecutor is established systemically as the 'guardian' of the rule of law, that is, an entity that watches over the due and lawful operation of state bodies. A public prosecutor acting in legal proceedings is also a 'guardian of the public interest'. ${ }^{21}$ Therefore, an effective guarantee of the protection of the rule of law in the performance of a public prosecutor's tasks is to undertake checks aimed at eliminating a state contrary to the law, caused by the actions of a public administration body. When analyzed in this spirit, the act stipulates that where criminal content is found, a public prosecutor may request a service provider or its country representative to send the necessary information, particularly regarding user data and publications posted on the online social networking site. The content of a criminal nature includes

18 | Art. 19 (2): A service provider is obliged to publish the terms of use of the social network site, in the Polish language, available to all users of the social network site, which also contain the rules for conducting internal audit and check processes. The terms of use may not be in conflict with the provisions of generally applicable law.

19 | Art. 19 (3): A service provider is also obliged to ensure that complaints are sent in an internal audit and check process in a clearly visible, directly and permanently accessible manner.

20 | Art. 25 (1): As a result of the conducted proceedings, the Council issues a decision in which: 1) it either orders the restoration of the previously limited access to content or the previously limited access to the user's profile, if it finds that the content or user profile to which access was limited do not constitute illegal content; or 2) refuses to restore the previously limited access to content or the previously limited access to the user's profile, if it finds that the content or user's profile to which access was limited constitute illegal content. 2 . The Council issues a decision within 7 days of the date of receipt of the complaint.

21 | Szubiakowski, Wierzbowski, and Wiktorowska, 1998, p. 251. 


\section{Marcin WIELEC}

Criminal Law Aspects of Combating Fake News in Poland

publication with pornographic content with the participation of a minor or content that praises or incites to commit acts of a terrorist nature. Access to the publication creates the risk of causing significant damage or causing effects that are difficult to reverse, a public prosecutor immediately issues an order for a service provider to prevent access to such content. This order is immediately enforceable. A copy of the order is delivered to the e-mail address of the country representative. A complaint to any such order may be filed with the district court having territorial jurisdiction for the public prosecutor who issued the order. Proceedings to examine the complaint is carried out pursuant to the Code of Criminal Procedure Act of June 6,1997.

Another interesting construction in the draft act is a 'name-blind civil action', which has so far been unknown in the Polish legal system. It is an instrument that enables an action to be brought to court to protect personal rights in the event of activities based on, for example, fake news. The interesting thing about this construction is that the statement of claim in this action does not indicate the respondent's details. By their nature, these details are extremely important for each statement of claim understood as a pleading to initiate a specific court process brought by a specific claimant against a specific respondent. The details identifying both the claimant and the respondent have been necessary to bring any type of action to court under Polish law. However, in the construction of the 'name-blind civil action', for the lawsuit to be filed effectively, it is sufficient to indicate the URL where the offensive content was posted, the date and time of publication, and the name of the user profile or log in.

\section{Conclusions}

The presented analysis shows that criminal liability for fake news is not strictly provided in the Polish criminal law system. This means that the basic legal Act in the form of the Penal Code does not list prohibited acts that directly involve the creation, dissemination, or changing information to the extent that it becomes a carrier of false content.

Criminal law, however, is a specific law in any legal system. Therefore, criminal law should deal with fake news of the greatest impact, that is, disinformation that threatens the highest values, such as state security. Disinformation of minor importance should be addressed in other branches of law, such as civil law, administrative law, and disciplinary law. To answer the question of whether there is a possible punishment for fake news, it is necessary to balance the conflict between the constitutional value of freedom of expression and the construction of a fake news offense. To have disinformation covered under criminal law, one must start off by establishing a catalogue of types of conduct and behaviors that make up this type of offense. Compiling such a catalog is very difficult. Therefore, there are and will be difficulties in the legal definition of fake news; therefore, it will also be difficult to prove this type of offense in a criminal trial. However, the legislative work agenda in Poland features a draft act on the protection of the freedom of social network users. It is a thorough administrative regulation, and this character of the act should be preserved. Criminal law should always be used as a last resort in ultima ratio regulation. 


\section{Bibliography}

I Skorupka, J. (ed.). (2017) Proces karny. Warszawa: Wolters Kluwer.

I Knosala,E. (2011) Zarys teorii decyzji wnauce administracji. Warszawa: Wolters Kluwer.

Wielec, M. (2017) Wartości - analiza z perspektywy osobliwości postępowania karnego, Lublin: Academicon.

Palczewski, M. (2019) 'Dyskurs fake newsa', Annales Universitatis Paedagogicae Cracoviensis, Studia de Cultura, 11(1), pp. 15-31.

Daniel, K. (2018) 'Media wobec fake newsów - motywy kreowania, przyjmowane postawy, podejmowane działania', Polityka i Społeczeństwo, 2018/3, pp. 95-114.

Szubiakowski, M., Wierzbowski, M., Wiktorowska, A. (1998) Postępowanie administracyjne - ogólne, podatkowe, egzekucyjne. Warszawa: C. H. Beck. 